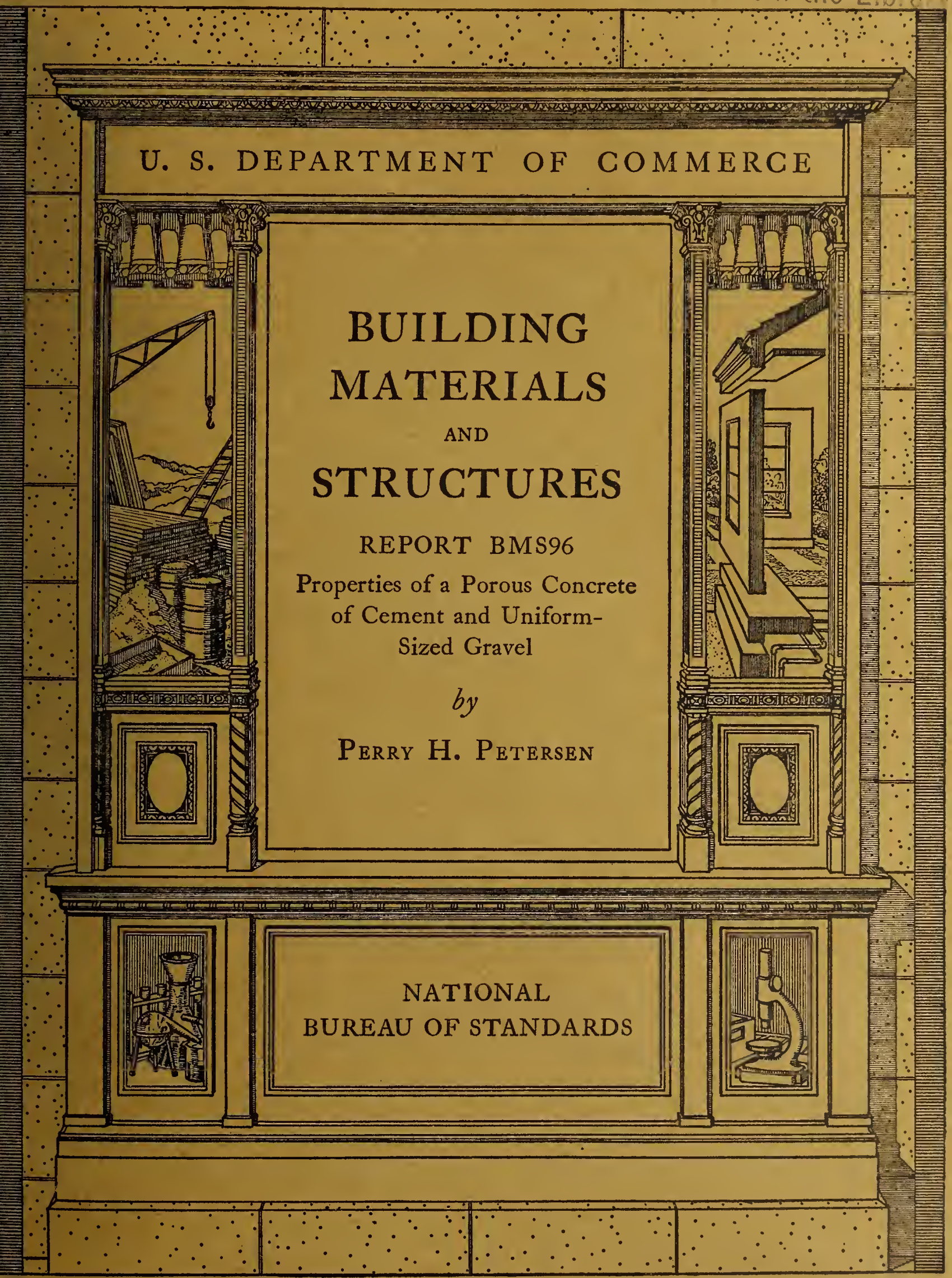




\section{BUILDING MATERIALS AND STRUCTURES REPORTS}

On request, the Superintendent of Documents, U. S. Government Printing Office, Washington, D. C., will place your name on a special mailing list to receive notices of new reports in this series as soon as they are issued. There will be no charge for receiving such notices.|

An alternative method is to deposit with the Superintendent of Documents the sum of $\$ 5$, with the request that the reports be sent to you as soon as issued, and that the cost thereof be charged against your deposit. This will provide for the mailing of the publications without delay. You will be notified when the amount of your deposit has become exhausted.

If 100 copies or more of any report are ordered at one time, a discount of 25 percent is allowed. Send all orders and remittances to the Superintendent of Documents, U. S. Government Printing Office, Washington, D. C.

The following publications in this series are available by purchase from the Superintendent of Documents at the prices indicated:

BMS1 Research on Building Materials and Structures for Use in Low-Cost Housing BMS2 BMS3

BMS4

BMS5

BMS6

BMS7

BMS8

BMS9

Methods of Determining the Structural Properties of Low-Cost House Constructions...

Suitability of Fiber Insulating Lath as a Plaster Base

Accelerated Aging of Fiber Building Boards_... B.

Structural Properties of Six Masonry Wall Constructions

Survey of Roofing Materials in the Southeastern States

Water Permeability of Masonry Walls

Methods of Investigation of Surface Treatment for Corrosion Protection of Steel

Structural Properties of the Insulated Steel Construction Co.'s "Frameless-Steel" Con-

BMS10 Structural Properties of One of the "Keystone Beam Steel Floor" Constructions Sponsored by the H. H, Robertson Co Fabrihome Corporation's "Fabrihome" Constructions for Walls and Partitions.

BMS11

BMS12 ctural Properties of "Steelox" Constructions for Walls, Partitions, Floors, and Roofs Sponsored by Steel Buildings, Inc...

BMS13 Properties of Some Fiber Building Boards of Current Manufacture

BMS14 Indentation and Recovery of Low-Cost Floor Coverings

BMS15 Structural Properties of "Wheeling Long-Span Steel Floor" Construction Sponsored by

BMS16 Structural Properties of a "Tilecrete" Floor Construction Sponsored by Tilecrete Floors, Inc - Pulation of Wall and Floor Constructions

BMS17 Sound Insulation of Wall and Floor Constructions

Supplement to BMS 17, Sound Insulation of W all and Floor Constructions

BMS18 Structural Properties of "Pre-fab" Constructions for Walls, Partitions, and Floors Sponsored by the Harnischfeger Corporation

BMS19 Preparation and Revision of Building Codes
BMS20 Structural Properties of "Twachtman" Constructions for Walls and Floors Sponsored

BMS21 by Connecticut Pre-Cast Buildings Corporation Structural Properties of a Concrete-Block Cavity-Wall Construction Sponsored by the
National Concrete Masonry Association

BMS22 Structural Properties of "Dun-Ti-Stone" Wall Construction Sponsored by the W. E.

Dunn Manufacturing Co
Structural Properties of a Brick Cavity-Wall Construction Sponsored by the Brick

BMS23 Manufacturers Association of New York, Inc
Structural Properties of a Reinforced-Brick Wall Construction and a Brick-Tile Cavity-
Wall Construction Sponsored by the Structural Clay Products Institute-
Structural Properties of Conventional Wood-Frame Constructions for Walls, Partitions, Structural Properties of a Reinforced-Brick Wall Construction and a Brick-Tile Cavity-
Wall Construction Sponsored by the Structural Clay Products Institute
Structural Properties of Conventional Wood-Frame Constructions for Walls, Partitions,

BMS24 Floors, and Roofs

BMS25

BMS26

Structural Properties of "Nelson Pre-Cast Concrete Foundation" Wall Construction Sponsored by the Nelson Cement Stone Co., Inc

BMS27 Structural Properties of "Bender Steel Home"' Wall Construction Sponsored by the Bender Body Co

BMS28

BMS29

BMS30

Backflow Prevention in Over-Rim Water Supplies

Survey of Roofing Materials in the Northeastern States Fir Plywood Association.....

BMS31 Structural Properties of "Insulite" Wall and "Insulite" Partition Constructions Sponsored by The Insulite Co 
UNITED STATES DEPARTMENT OF COMMERCE • Jesse H. Jones, Secretary NATIONAL BUREAU OF STANDARDS • Lyman J. Briggs, Director

\section{BUILDING MATERIALS and STRUCTURES

\author{
REPORT BMS96
}

Properties of a Porous Concrete of Cement and

Uniform-Sized Gravel

by

PERRY H. PETERSEN

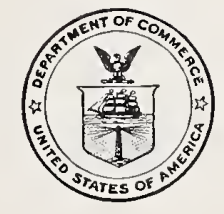

ISSUED MARCH 18, 1943

The National Bureau of Standards is a fact-finding organization; it does not "approve" any particular material or method of construction. The technical findings in this series of reports are to be construed accordingly

UNITED STATES GOVERNMENT PRINTING OFFICE・ WASHINGTON • I $9+3$ FOR SALE BY THE SUPERINTENDENT OF DOCUMENTS, U. S. GOVERNANT PRINTING OFFICE WASHINGTON, D. C. - PRICE IO CENTS 


\section{Foreword}

This report describes an investigation of physical properties of a porous concrete of cement and uniform-sized gravel, undertaken in cooperation with the Federal Public Housing Authority to determine the application of such a concrete in the construction of low-cost housing.

The technical facts presented provide data from which architects and engineers can determine whether performance requirements are met.

Lyman J. Briggs, Director. 


\title{
Properties of a Porous Concrete of Cement and Uniform-Sized Gravel
}

\author{
by PERRY H. PETERSEN
}

Foreword _.............. II

I. Introduction $\ldots \ldots \ldots$

II. Materials _............ 2

1. Cement .......... 2

2. Aggregate $\ldots \ldots \ldots \ldots 2$

III. Preliminary studies_._._.

1. Mixing the porous concrete _..... 2

2. Placing concrete in wall specimens_-- 2

3. Method of molding cylinders_._._. 3

4. Preliminary tests, using grits_..._._. 3

5. Preliminary tests, using pea gravel_._ 4

6. Preliminary tests, using $3 / 4$-inch gravel 4

IV. Description of specimens and test results_. 4

1. Transverse strength_._._....... 5

2. Heat-transfer properties_........ 6

(a) Specimens.............. 6

\author{
P
}

\section{ONTENTS}
IV. Deseription of specimens, ete-Continued. 2. Heat-transfer properties-Continued.
(b) Test equipinent and procedure_ 7
(c) Heat-transfer data and results.
3. Compressive strength
4. Shrinkage and thermal-expansion co- efficients_._.
5. Water penetration due to capillarity 11
6. Resistance to rain penetration _._. 11
(a) Specimens _.............. 11
(b) Test equipment and procedure. 11
(c) Test results_.............. 11
7. Bond strength _............ 11
8. Resistance to failure by diagonal tension_................. 13

V. Summary _._.

\begin{abstract}
The physical properties of a porous concrete consisting solely of portland cement, water, and uniform-sized gravel were investigated. Each of three coarse aggregates, grits (No. 8 to No. 4), pea gravel (No. 4 to $3 / 8$ inch), and $3 / 4$-inch gravel ( $3 / 8$ to $3 / 4$ inch), was used, with $2 \frac{1}{2}$ bags of cement per cubic yard in concrete tamped in place and 3 bags per cubic yard when no compacting was done. Walls, wallettes, beams, and bond pull-out specimens werc tested, as well as 6- by 12-inch control cylinders. Compressive, transversc, shearing, and bond strengths arc reported, as well as resistance to heat transfer, water penetration by capillarity, and rain penetration.
\end{abstract}

\section{INTRODUCTION}

Plain or with reinforcement, concrete is readily adaptable to most structures, the strength requirements being attained by the correct proportioning of the ingredients and the use of proper workmanship. There is being brought to the attention of the building industry at this time a type of porous concrete made solely of cement, gravel, and water, the gravel being of a uniform size. Since sand and other. size gravels are excluded in the proportioning of the ingredients and the cement content is kept down to about half that of the usual structural concrete, a highly porous material is obtained. Certain promising features of such a material were believed to warrant an examination of its physical properties. In some localities, there is an abundance of uniform-sized gravel compared with the supply of the graded aggregates used in regular concrete. Since no excess water is used, bleeding is eliminated and hydrostatic pressures do not exist, thereby allowing a rougher type of formwork.

This report deals with a porous concrete such as is obtained when using each of three different-sized aggregates. The methods of mixing and placing that were used are outlined, togetler with the various tests performed. The 
specimens were tested structurally for compressive, transvers', bond strength, and shear properties, as well as heat transfer, water capillarity, and resistance to rain penctration.

\section{MATERIALS}

\section{Cement}

The cement used was North American brand portland cement.
2. AgGREGATE

Thre aggregate was Potomac River gravel of three different sizes, namely, grits, pea gravel, and a $3 / 4$-in. gravel. The grits and pea gravel were obtained commercially as such, but the 3/4-in. gravel was screened at the Bureau from commercial 3/4-in. gravel. The sieve analyses are given in table 1. The absorption, apparent specifie gravity, and the bulk specific gravity on a surface dry basis are given in table 2 .

TABLE 1.- Sieve rinalyses of aggregates

\begin{tabular}{|c|c|c|c|c|c|c|c|c|c|}
\hline \multirow{2}{*}{ T. S. Standard sieve } & \multicolumn{8}{|c|}{ Percentage, passing, by dry weight } & \multirow{2}{*}{$\begin{array}{l}\text { Fineness } \\
\text { modulus }\end{array}$} \\
\hline & $1 \mathrm{in.}$ & ${ }^{3}+\mathrm{in}$. & $1 / 2$ in. & 38 in. & No. 4 & No. 8 & No. 16 & No. 30 & \\
\hline $\begin{array}{l}\text { Crits } \\
\text { Pea gravel } \\
\text { "y-in gravel }\end{array}$ & 100 & 96 & $\begin{array}{r}100 \\
31\end{array}$ & $\begin{array}{r}100 \\
9 x \\
2\end{array}$ & $\begin{array}{r}91 \\
25 \\
0\end{array}$ & $\begin{array}{r}27 \\
2\end{array}$ & $\begin{array}{l}5 \\
1\end{array}$ & $\begin{array}{l}2 \\
0\end{array}$ & $\begin{array}{l}\text { 4. } \\
5.7 \\
7.11\end{array}$ \\
\hline
\end{tabular}

TABLE 2.-Data on ingredients and mixtures

Absorption, percentage by dry weight a

Bulk specific gravity, surfaee dry basis

Apparent specific gravity :

Sieve analyses limits (approx.)

Cement content

Method of placin

1)ry aggregate per bag of cement

Water-coment ratio by weight

V'eight of fresh concrete bags per eu yd

ib

$\mathrm{lb} / \mathrm{Ct}^{3}$.

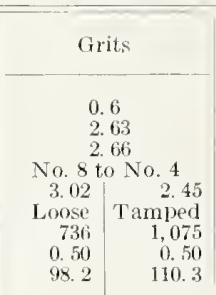

\begin{tabular}{|c|c|}
\hline \multicolumn{2}{|c|}{ Pea gravel } \\
\hline \\
\hline & 56 \\
\hline & \\
\hline No. 4 & $0,38 \mathrm{in}$. \\
\hline 2.95 & 2. 51 \\
\hline Loose & Tamped \\
\hline 750 & 1,085 \\
\hline 0.50 & 0.50 \\
\hline 97.1 & 113.9 \\
\hline
\end{tabular}

3/-in. grave

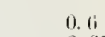

0.6
2.61

2. 61
2.64

$3 \times$ in. to $3 / 4$ in 3.16 2.51

Locse Tamped

$770 \quad \mathrm{~J}, 100$

$\begin{array}{rr}0.40 & 0.44 \\ 105.5 & 114.9\end{array}$

a Determined aceorling to the ASTM Standard Test Method C 127-39

\section{PRELIMINARY S'TUDIES}

A preliminary investigation was conducted to develop techniques in mixing and placing the porous concrete and molding representative cylinders, and to obtain approximate values of compressive and transverse strengths.

\section{Mixing the Porous Concrete}

A rotary drum-type mixer was used and found satisfactory, although the paddle type is recommended by some investigators. In charging the mixer, part of the required water was put in first, followed about 15 seconds later by the gravel and cement. By this procedure, rach batch gained some cement adhering to the inside of the mixer from the previous batch, but lost about the same amount to the following one. Care was taken to add just enough water during the mixing to produce a sheen to the cement coating on each particle of gravel so that, wherever any two particles touched, a meniscus of cement slurry was formed of considerably greater area than the actual contact surfaces. The total mixing time was kept between $2 \frac{1 / 2}{1}$ and 3 minutes.

\section{Placing Concrete in Wali Specimens}

'Two methods of placing the porous concrete were used, namely, the loose and the tamped. The designation loose signifies that the concrete was poured into the forms and allowed to settle in place without any tamping, rodding, or other compacting. The designation tamped signifies that the concrete was compacted in place with wood tampers of end dimensions $2 \frac{1}{2}$ by $4 \mathrm{in.}$

A trial wall, $100 \mathrm{in}$. high, $56 \mathrm{in.}$ long, and 3 in. thick, was made, using grits as the aggregate. The concrete in the lower half was tamped in place and in the upper half placed loose. No difficulty was experienced in placing the concrete by either method in a wall of 
this thiekness. Upon stripping the forms, the surface texture of both halves was similar to that shown for grits in figure 1.

Figure 1 illustrates the difference in texture of the walls made with the three aggregates, the concrete in the specimen on the left in each group having been tamped, and that on the right having been placed in the loose condition. It is to be noted that a surface finish such as plaster, stucco, or a grout is required for this type of concrete, in order to prevent unraveling of the aggregate at the surface when the walls are subjected to any abuse.

\section{Method of Molding Cylinders}

Cylinders were molded in two different ways to correspond to the method used in placing the eoncrete in the wall specimens. For the loose condition, eylinders were made by dribbling the fresh concrete from a seoop against the inside face of the mold in small quantities and the top finished off with a trowel, compacting about a 2 -in. mound of exeess material into the eylinder. Tamped cylinders were made by tamping the concrete 25 times in each of 3 layers, using a length of pipe with a eap of 2 -in. outside diameter, the whole weighing about $5 \mathrm{lb}$.

\section{Preliminary Tests, Using Grits}

Sinall walls or wallettes, $6 \mathrm{in.}$ thiek, $30 \mathrm{in}$. high, and $30 \mathrm{in}$. wide were made of grits with eement contents of $2 \frac{1}{2}$ and 4 bags per cu yd, each in the tamped and in the loose condition. The compressive tests of the wallettes, load applied to the top ( 6 by $30 \mathrm{in}$.), were made at the age of 7 and 28 days, and the transverse tests were made at 7 days with the walls in a horizontal position, eentrally loaded on a span of $24 \mathrm{in}$. The compressive strengths are shown in figure 2. Two sets of eylinders were molded from the batches for each compressive-test wallette, one set placed loose, and one tamped, regardless of whether the concrete for the wallette was tamped or placed loose. Thus, eylinder strengths are also shown for two other coment contents, the cement content being computed from the actual weight of the cylinders upon stripping the molds $24 \mathrm{hr}$ after molding.

The moduli of rupture of the wallettes at 7
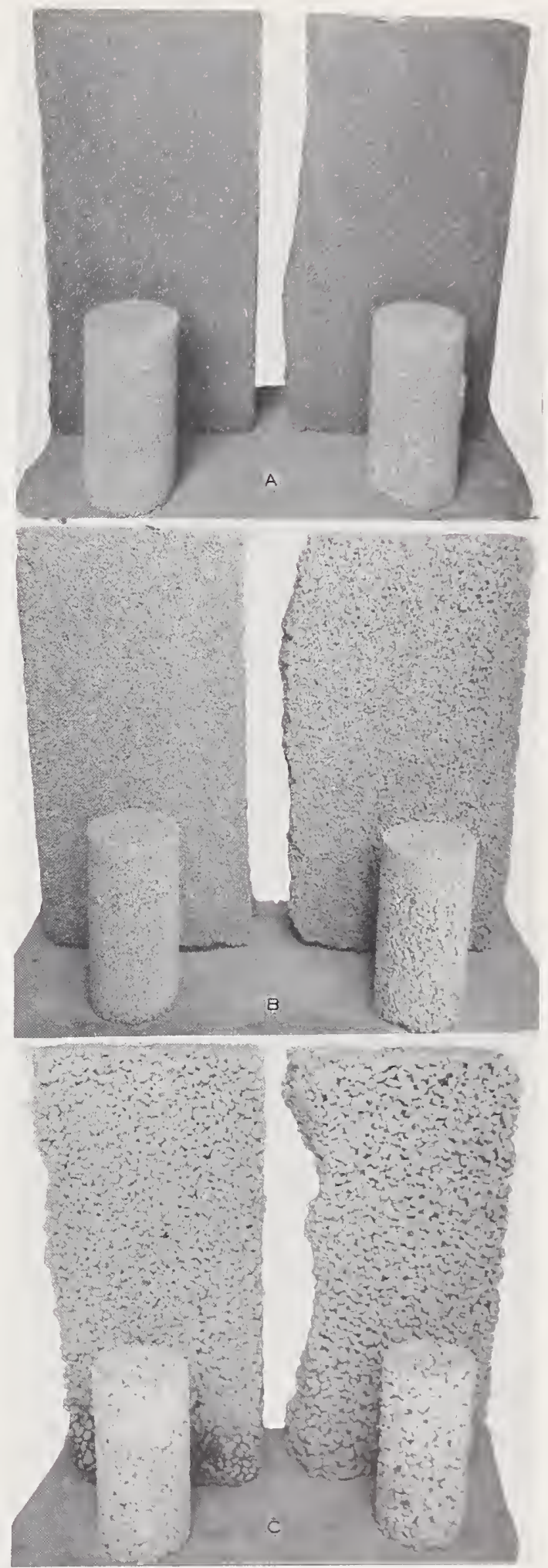

Figure 1.- Walls of porous concrete.

1, Grits, $B$, Pea gravel; $C, 3 /$-in. gravel. Specimen on left, concrete was tarnped in place, specimen on right, concrete ras placed in loose condition. 


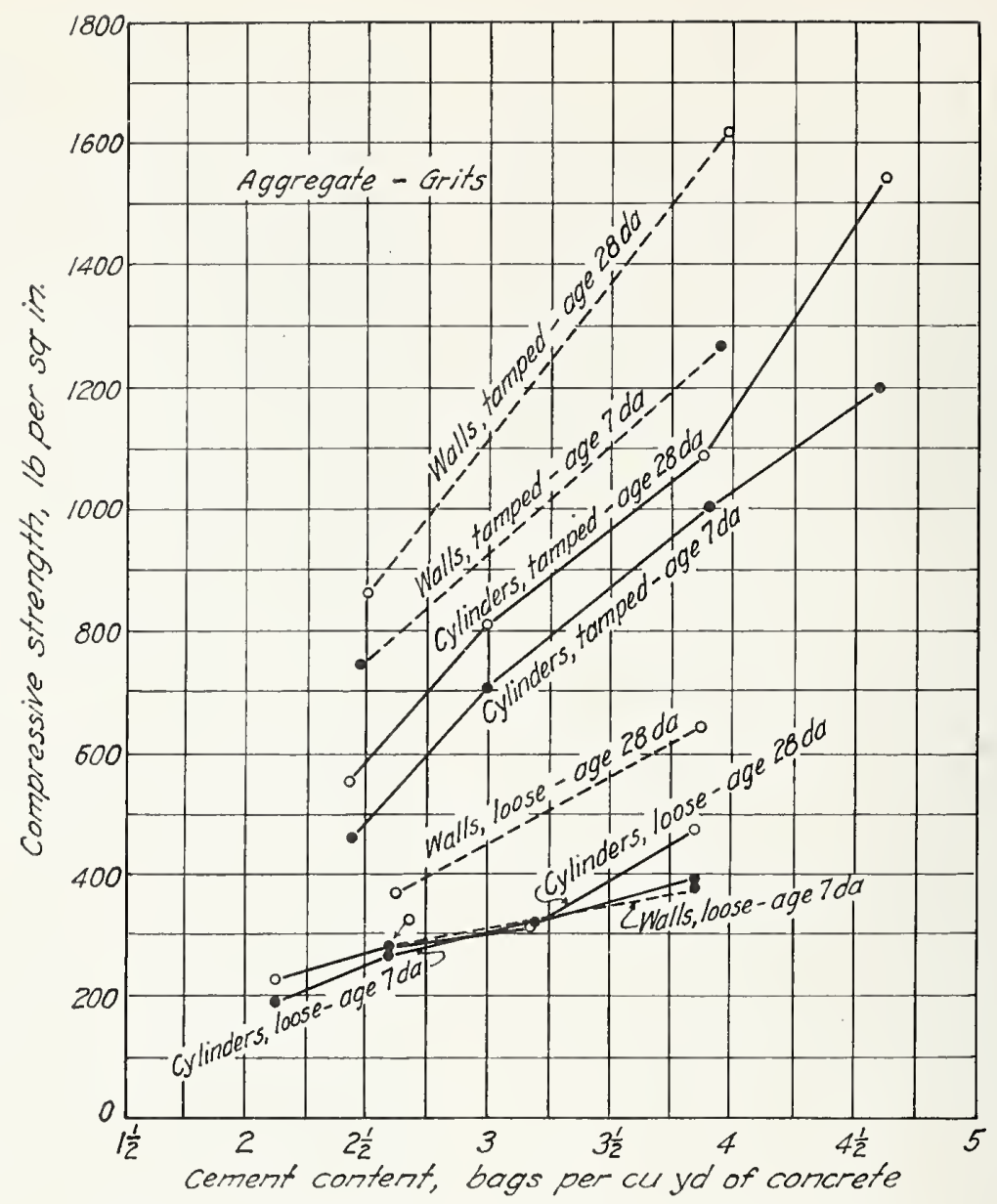

FIGURE 2. Compressive strength of porous concrete, using grits.

days were, respectively, 44 and $73 \mathrm{lb} / \mathrm{in}^{2}$ for the 21/2- and 4-bag mixes placed loose, and 78 and $178 \mathrm{lb} / \mathrm{in}^{2}$ for the $2 \frac{1}{2}$ - and 4 -bag mixes tamped in place.

\section{Prelminary Tests, Using Pea Gravel}

The same two mixes of $2 \frac{1}{2}$ and 4 bags of cement per cu yd, placed loose and tamped, using pea gravel, were used in the 7 -day compressive tests, and the transverse tests were made at 7 days for both the 21/2-and 4-bag mixes placed loose. Three cylinders loose and three tamped were made along with each wallette, whether or not the concrete in the wallette was placed loose or tamped. The compressive strengths of the wallettes and cylinders are shown in figure 3 . The moduli of rupture at 7 days were, respectively, 39 and $72 \mathrm{lb} / \mathrm{in}^{2}{ }^{2}$ for the $21 / 2$ - and 4-bag mixes placed loose.
6. Premiminary Tests, Using 3/4-In. Gravel

Tests were also made with the $3 / 4$-in. gravel in the same way as was done with the pea gravel. The compressive test results of wallettes and cylinders are shown in figure 4 . The moduli of rupture at 7 days were, respectively, 61 and 98 $\mathrm{lb} / \mathrm{in}^{2}{ }^{2}$ for the $2 \frac{1}{1} 2^{-}$and 4 -bag mixes placed loose.

\section{DESCRIPTION OF SPECIMENS AND TES'T RESULTS}

In these tests, each of the three aggregates was used with a cement content of 3 bags per cu yd in concrete placed loose, and $2 \frac{1}{2}$ bags per cu yd tamped in place. Records were kept of batch weights, amounts of water, and weights per cubic foot of wet concrete; the latter was determined with a standard cubicfoot measure. These data are shown in table 2. 


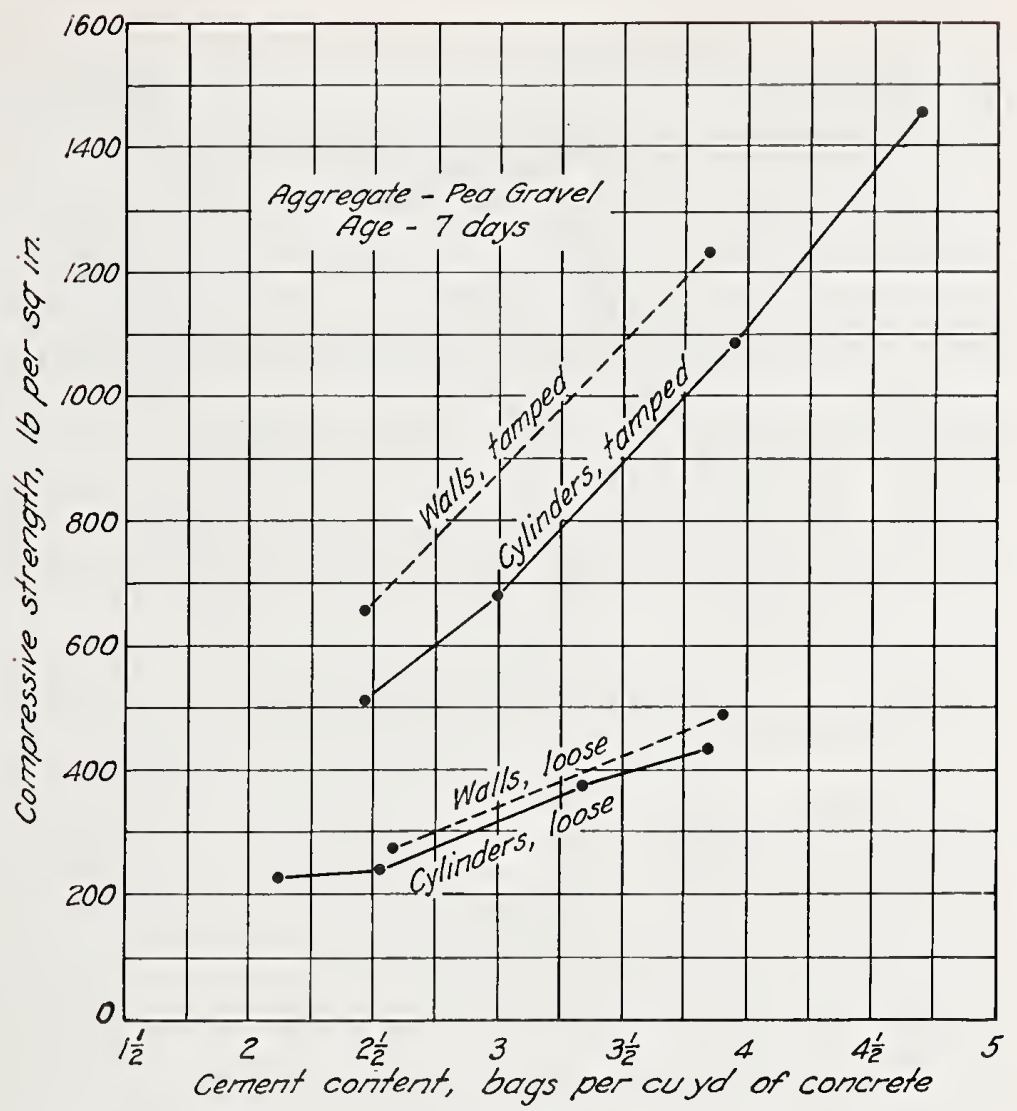

HigURE 3.-Compressive strenglh of porous concrete, using pea gravel.

All the walls were 6 in. thick, and the resi cylinders were of the standard 6 - by 12 -in. size. The forms were made of $5 / 8$-in. plywood, with 2- by 4 -in. studs, 4 - by 4 -in. wales, and 2 - by 6 -in. end forms. To facilitate handling, all the walls were built on steel channels.

\section{Transverse Strength}

The wallettes for transverse tests were 6 by 30 by 30 in., as in the preliminary tests, and four of each mixture were made. Two wallettes were monolithic and two had horizontal transverse joints at midheight, the top laalf being poured $24 \mathrm{hr}$ after the bottom half, without any grouting or extra preparation of the bonding surfaces. These wallettes were left without a surface finish and were tested at 28 days, together with their respective cylinders. The moduli of rupture are given in table 3 , together with the compressive strength of the cylinders. Shown in figure 5 is the $3 / 4-\mathrm{in}$.gravel wallette, concrete placed loose, with a cement content of 3 bags of cement. The wallette lies horizontally for the transierse test on a span of $24 \mathrm{in}$. between rollers; the load being applied along the center line.

TABLE 3.- Moduli of rupture of walls and compressive strength of cylinders of porous concretes

\begin{tabular}{|c|c|c|c|c|c|c|}
\hline \multirow{2}{*}{ Aggregate Normal cement content } & \multicolumn{2}{|c|}{ Grits } & \multicolumn{2}{|c|}{ Pea gravel } & \multicolumn{2}{|c|}{ 3itin. gravel } \\
\hline & & & & & & \\
\hline Method of placing & Loose & Tamped & Loose & Tamped & Loose & Tamped \\
\hline $\begin{array}{l}\text { odulus of rupture of monolithic walls } \\
\text { Compressive strength of cylinders }\end{array}$ & $\begin{array}{r}96 \\
410\end{array}$ & $\begin{array}{l}135 \\
590\end{array}$ & $\begin{array}{r}82 \\
+10\end{array}$ & 96 & $\begin{array}{r}85 \\
580\end{array}$ & $\begin{array}{l}101 \\
930\end{array}$ \\
\hline Modulus of rupture of transverse joint walls & 38 & 22 & 39 & 26 & 54 & $(\mathrm{~b})$ \\
\hline Compressive strength of cylinders & 410 & 600 & 390 & 720 & 580 & (b) \\
\hline
\end{tabular}

a See table 2 for actual cement content

b Transversc-joint walls not made. 


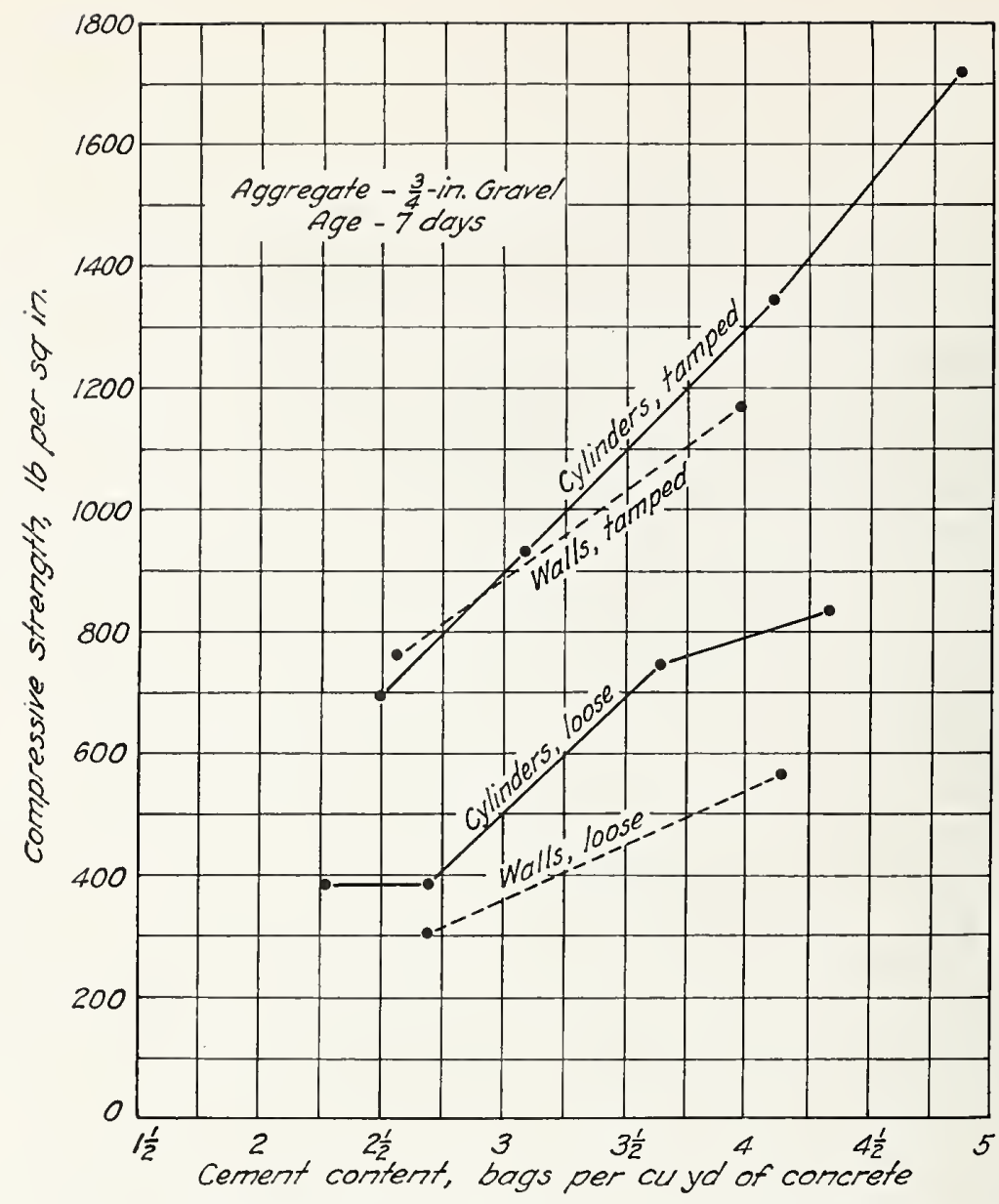

Figdre 4.-Compressive strength of porous concrete, using 3/4-in. gravel.

\section{Heat-Transfer Properties}

\section{(a) Specimens}

One wall of each mixture was made for the heat-transfer tests, the walls being $100 \mathrm{in}$. high, $6 \mathrm{in}$. thick, and $56 \mathrm{in}$. wide. As the walls were highly porous and offered little resistance to the transmission of air, they were finished, 2 weeks after pouring them, with a $1 / 8-i n$. coating of stucco on the weather face and two coats of cement-water paint on the edges, top, and other face.

The stucco was proportioned $1: 0.2: 3.0$ by dry weight of North American brand portland cement, Miracle brand hydrated lime, and Potomac River building sand. It was troweled on to about $1 / 8-i n$. thickness and, after the preliminary 'set had taken place, was brushed with a wet whitewash brush to eliminate the trowel marks.
'The coment-water paint was applied in two coats, $24 \mathrm{hr}$ apart, the first being in the proportions of $1: 0.25: 1.0$ by dry weight of white portland cement, Miracle brand hydrated lime, and Potomac River building sand passing a No. 30 sieve. The finish coat was 1:0.25 of white portland cement and hydrated lime. Both coats of cement-water paint were applied to the walls made of grits and pea gravel, using a roofers brush. However, on the $3 / 4$-in.-gravel walls, a fender brush was used for the first coat and the roofers brush for the second coat.

The approximate quantities of the matcrials for surface finishes used on each wall are given in table 4 . These values may vary with any slight increase or decrease in the thickness of the stucco or with any change in consistency or brushing technique in applying the cementwater paint. 


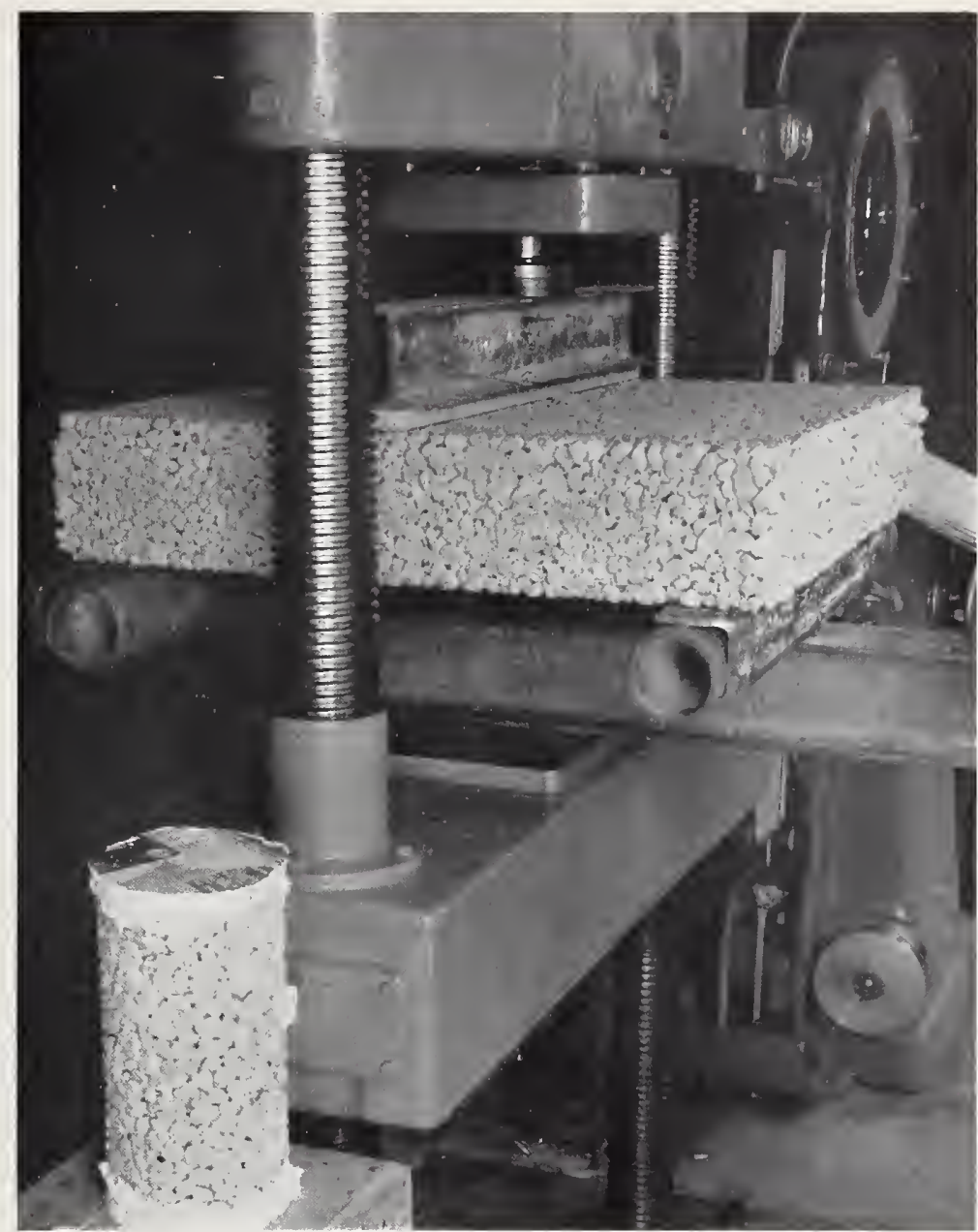

Figure 5.-Transverse test.

\section{(b) Test Equipment and Procedure}

The heat-transfer tests were conducted in the shielded hot-box apparatus by the Heat Transfer Scction at this Burcau. During the test, heat flowed from the metering and shield boxes, which were heated electrically, through the wall to the cold box, which was cooled by a refrigerating machine. The electric energy supplied to the metering box and measured by

TABLE 4.-Quantities of materials used for wall-surface finishes

\begin{tabular}{|c|c|c|c|c|c|c|}
\hline Aggregate.... & \multicolumn{2}{|c|}{ Grits } & \multicolumn{2}{|c|}{ Pea gravel } & \multicolumn{2}{|c|}{ 3i-in. gravel } \\
\hline $\begin{array}{l}\text { Nominal cement eontent } \\
\text { Method of plaeing }\end{array}$ & 3 & $21 / 2$ & 3 & 21,5 & 3 & $21 / 2$ \\
\hline Stueeo materials: & Loose & Tanped & Loose & Tамреа & Loose & 1 amped \\
\hline Cement & 0.53 & 0.53 & 0.59 . & 0.53 & 0.80 & 0.64 \\
\hline Hydrated lime. & .11 & .11 & .12 & .11 & .16 & .13 \\
\hline Sand ................ & 1.59 & 1.59 & 1.76 & 1.59 & 2,40 & 1.91 \\
\hline \multicolumn{7}{|l|}{$\begin{array}{l}\text { Cement-water paint materials: } \\
\text { First coat: }\end{array}$} \\
\hline Cement & (b) & (b) & .29 & .20 & .46 & .33 \\
\hline Hydrated lime. & (b) & (b) & .07 & .05 & .12 & .08 \\
\hline Sand $\ldots . . . .$. & (b) & (b) & 29 & .20 & .46 & .33 \\
\hline Second coat: & & & & & & \\
\hline Cement . . ....... & (b) & (b) & .10 & .07 & .12 & .12 \\
\hline Hydrated lime... & (b) & (b) & .03 & .02 & .03 & .03 \\
\hline
\end{tabular}

a See table 2 for aetual eement content.

b Quantities were not obtained.

$511094^{\circ}-43-2$ 
a watthour meter was taken as closely equivalent to the heat energy transferred through the area of the specimen covered by the metering box. The temperatures in the metering and in the shield boxes were the same and kept at $70^{\circ} \pm 0.5^{\circ} \mathrm{F}$, whereas that in the cold box was at $0^{\circ} \pm 0.5^{\circ} \mathrm{F}$. The stuceo face, designated as the weather side of the wall, was turned against the eold box, and the cement-water paint surfaee was used at the hot-box side.

\section{(c) Heat-Transfer Data and Results}

The results of the observations on heat transfer are given in table 5, the heat transmission of the specimens being expressed in three ways. Two include the effect of surface coefficients, and a third is independent of them. The first result, the observed thermal transmittance, $u$, is the number of Btu per hour trans- mitted through each square foot of specimen for each degree Fahrenheit temperature difference of the air on opposite sides of the walls. This value ineludes the observed surface coefficients, $f$ and $f o$, as shown in the table. The second value for thermal transmittance, shown as $U$, is corrected to agree with the conditions recommended in the ASHVE "Guide" for 15 mpl wind outside and zero wind inside, using surface coefficients of 1.65 and 6.00 for $f$ and $f_{0}$, respectively. The third value, $C$, the thermal conductance, represents the number of Btu per houl transmitted through each square foot of specimen for each degree Fahrenheit temperature difference between the surfaces of the two sides of the wall and is therefore independent of the surface coefficients. The thermal conductivity, $k$, is equivalent to the conductance of the material per inch of thickness.

TABLE 5.-Ileat-transfer coefficients a

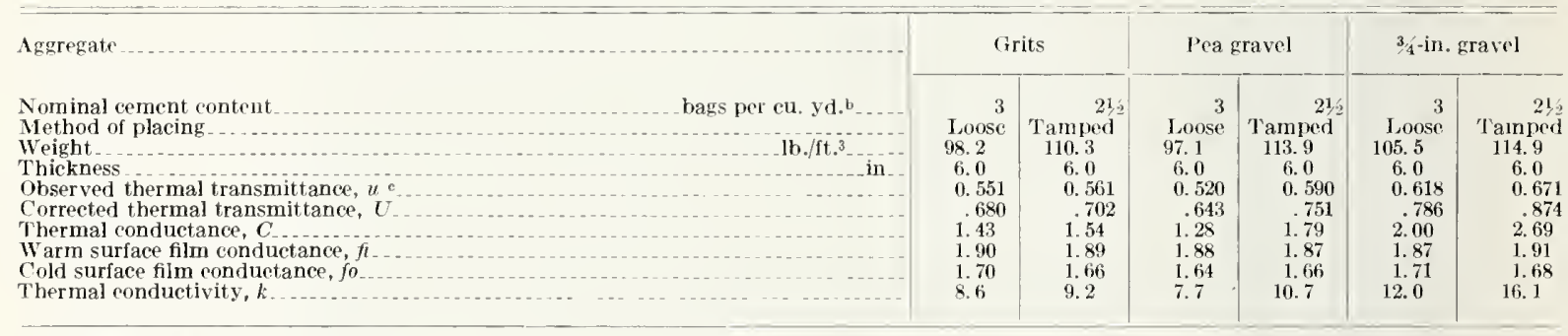

a Determined by shielded hot-box apparatus. Cold side of wall finished with $1 / 8$-in. stueco. Warm side of wall finished with 2 eoats of ceulentwater paint.

See table 2 for actual cement content.

The definitions of $u, U, C$, and $k$, representing the various coefficients of heat $t$ rausmission, are:

$u=$ number of Btu per hour transmitted through each square foot of specimen for each degrce Fahrenheit difference in temperaturc between the air on the 2 sides, as observed under test conditions.

$U=u$ corrected for a $15-\mathrm{mph}$ wind outside and zero wind inside by means of the factors $f=1.65$ and $f 0=6.00$ taken from the A SH V E "Guide." mber of Btu per hour transmitted through each square foot of specimen for each degrec Fahrenheit temperature difference between the sur-

$k=$ The thermal conductivity of the naterial, equivalent to the conductance per inel of thiekness.

\section{Compressive Strrength}

Compressive tests at an age of 7 weeks were made with wall specimens of two sizes. The walls which had been previously tested for heat-transfer properties at 4 weeks were used as one of the compression specimens. A wallette was also tested in compression at the same age, this speeimen having been made and the surface finished like the larger wall and at the same time.

Shown in figure 6 is the wall made of $3 / 4-\mathrm{in}$. gravel, using 3 bags of cement, the concrete placed in the loose condition. During the compressive test, deformation readings were taken with a 20 -in. Whittemore strain gage on three vertical lines, on each face of the wall, for uniform increments of load. The average secant modulus of elasticity at an applied stress of 200 lb./in. ${ }^{2}$ is given in table 6 , together with the maximum compressive strengths of walls and cylinders. The dispersions of the strength values of the individual cylinders from the mean were greater than is usual with workable dense concretes.

Figure 7 shows the 30 -in. wallette set up for compressive test. The face shown is stuccoed, ans the edge and back face are cement-water painted. The top and bottom were capped previous to the test with a Lumnite cement mortar. 


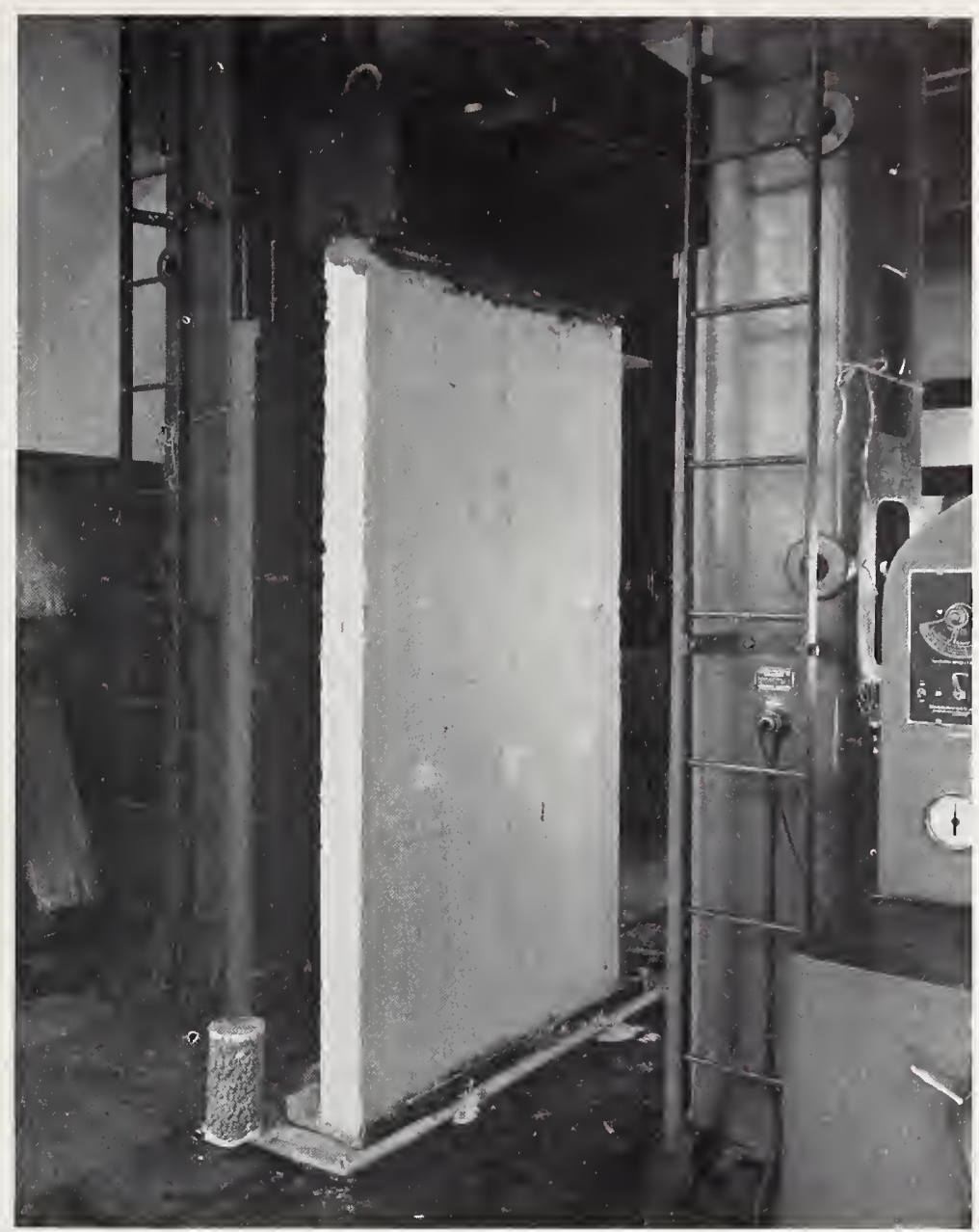

Figure 6.-Compression test of 100 by 56 by 6 in. wall

\section{Shrinkage and Thermal-expansion}

\section{Confficients}

For determining the amount of shrinkage and the coefficients of thermal expansion, one 30-in. wallette was built for each mixture. On both faces, there were four 20-in. gage lines, two horizontal and two vertical, each 5 in. from the edges of the walls. Observations were made approximately once a week with a Whittemore strain gage. The syecimens were allowed to remain in the laboratory, where neither temperature nor humidity was controlled. After they had aged at least 3 months, they were stored in a drying room, kept at $95^{\circ}$ to $100^{\circ} \mathrm{F}$, and after drying them, a set of observations was taken. Then, they were

TABLE 6.-Compressive strength and secant modulus of elasticity

\begin{tabular}{|c|c|c|c|c|c|c|}
\hline Aggregate & \multicolumn{2}{|c|}{ Grits } & \multicolumn{2}{|c|}{ Pea gravel } & \multicolumn{2}{|c|}{ 3/4-in. gravel } \\
\hline $\begin{array}{l}\text { Nominal cement content } \\
\text { Method of placing }\end{array}$ & $\begin{array}{r}3 \\
\text { Loose }\end{array}$ & Tamped & $\begin{array}{r}3 \\
\text { Loose }\end{array}$ & Tamped & $\begin{array}{r}3 \\
\text { Loose }\end{array}$ & Tamped \\
\hline $\begin{array}{l}\text { Compressive strength: } \\
\text { Walls } 56 \text { by } 100 \text { by } 6 \text { in } \\
\text { Cylinders. } \\
\text { Wallette } 30 \text { by } 30 \text { by } 6 \text { in } \\
\text { Cylinders }\end{array}$ & $\begin{array}{l}647 \\
491 \\
714 \\
469\end{array}$ & $\begin{array}{l}665 \\
582 \\
995 \\
626\end{array}$ & $\begin{array}{l}504 \\
447 \\
551 \\
380\end{array}$ & $\begin{array}{l}667 \\
645 \\
918 \\
654\end{array}$ & $\begin{array}{l}621 \\
520 \\
808 \\
700\end{array}$ & $\begin{array}{r}835 \\
930 \\
1,090 \\
947\end{array}$ \\
\hline $\begin{array}{l}\text { Secant modulus of elast leity at } 200 \mathrm{lb} / \mathrm{in}^{2} \\
\text { Wall } 56 \text { by } 100 \text { by } 6 \text { in }\end{array}$ & $1,010,000$ & $1,130,000$ & 830,000 & $1,210,000$ & $1,670,000$ & $2,080,000$ \\
\hline
\end{tabular}

- Sce tablc 2 for actual cement content. 


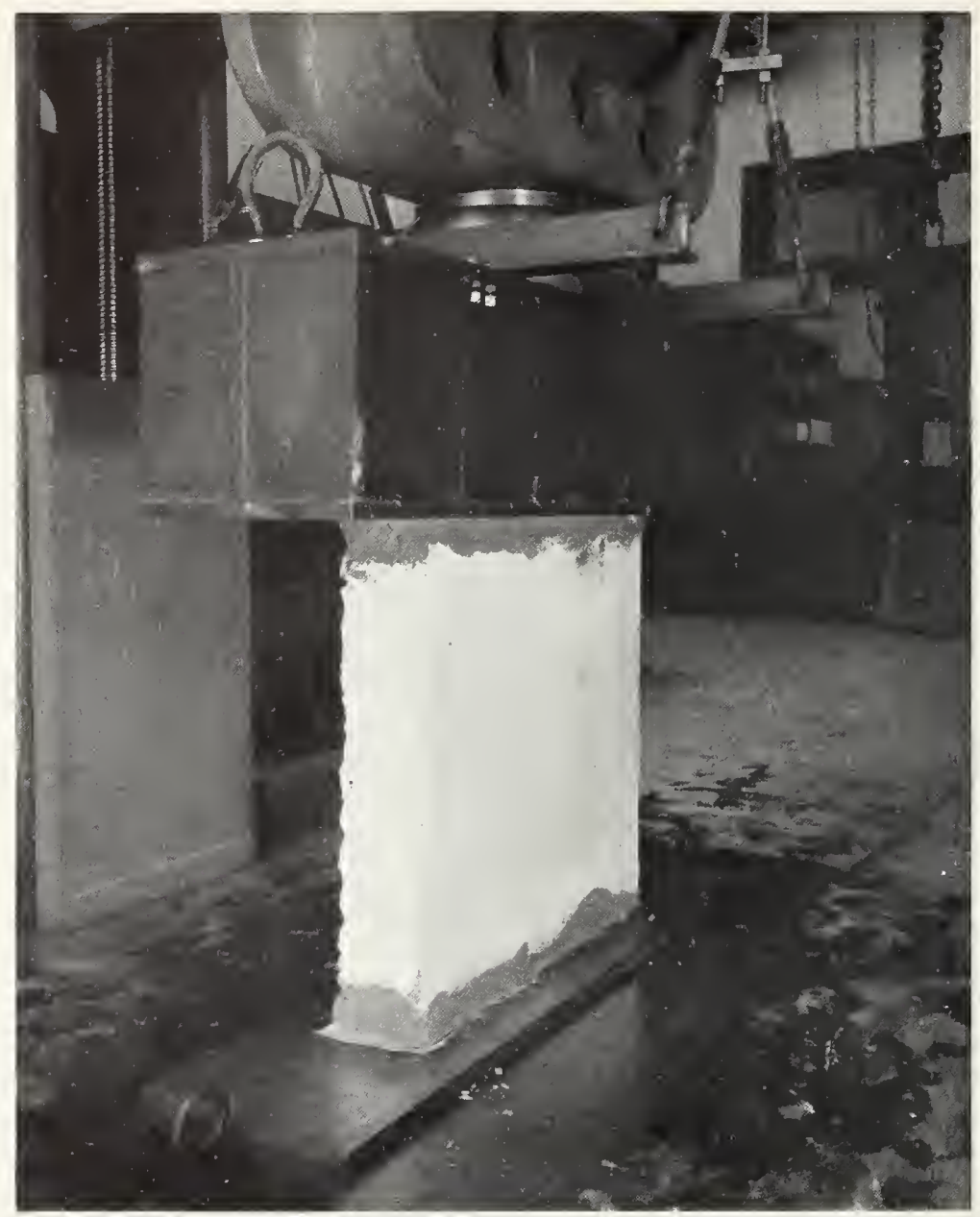

Figure 7.-Compression test of 30- by 30-by 6-in. walletle.

transferred to a cold room with a temperature between $8^{\circ}$ and $12^{\circ} \mathrm{F}$ and, when the temperature of the walls reached that of the room, a set of observations was made. After one more cycle of the hot and cold storage, the wallettes were returned to the drying room and the final observations taken after reaching temperature equilibrium. Shown in table 7 are the coeffi- cients of thermal expansion of each of the walls, together with the maximum amounts of shrinkage corrected for temperature, as evidenced in the drying room and in the laboratory prior to drying them. These shrinkages are the changes in length, based on original readings taken at an age of 2 or 3 days.

TABLE 7.-Shrinkage and thermal-expansion coefficients

\begin{tabular}{|c|c|c|c|c|c|c|}
\hline Aggregate & \multicolumn{2}{|c|}{ Grits } & \multicolumn{2}{|c|}{ Pea gravel } & \multicolumn{2}{|c|}{$3 / 4$-in. gravel } \\
\hline $\begin{array}{l}\text { Nominal cement content } \\
\text { Method of placing } \\
\text { Coefficient of thermal expansion per o }{ }^{\mathrm{F}} \mathrm{b}\end{array}$ & $\begin{array}{r}3 \\
\text { Loose } \\
6.1 \times 10^{-6}\end{array}$ & $\begin{array}{r}21 / 2 \\
\text { Tamped } \\
6.1 \times 10^{-6}\end{array}$ & $\begin{array}{r}3 \\
\text { Loose } \\
6.1 \times 10^{-6}\end{array}$ & $\begin{array}{r}21 / 2 \\
\text { Tamped } \\
6.0 \times 10^{-6}\end{array}$ & $\begin{array}{r}3 \\
\text { Loose } \\
6.1 \times 10^{-6}\end{array}$ & $\begin{array}{r}21 / 2 \\
\text { Tamped } \\
5.9 \times 10^{-6}\end{array}$ \\
\hline $\begin{array}{l}\text { Total shrinkage: } \\
\quad \text { Laboratory storage } \\
\text { Drying-room storage }\end{array}$ & $\begin{array}{r}0.038 \\
.052\end{array}$ & $\begin{array}{r}0.026 \\
.037\end{array}$ & $\begin{array}{r}0.029 \\
.041\end{array}$ & $\begin{array}{r}0.025 \\
.033\end{array}$ & $\begin{array}{r}0.012 \\
.015\end{array}$ & $\begin{array}{r}0.007 \\
.009\end{array}$ \\
\hline
\end{tabular}

a See table 2 for actual cement content.

$b$ Determined in the range of $10^{\circ}$ to $100^{\circ} \mathrm{F}$.

c Corrected for temperature. 
TaBLE 8.- Rise of uater due to capillarity

\begin{tabular}{|c|c|c|c|c|c|c|}
\hline Aggregate & \multicolumn{2}{|c|}{ Grits } & \multicolumn{2}{|c|}{ Peagravel } & \multicolumn{2}{|c|}{ y-in. gravel } \\
\hline $\begin{array}{l}\text { Nominal eement mixture } \\
\text { Method of placing. }\end{array}$ & $\begin{array}{r}3 \\
\text { Loose }\end{array}$ & Tamped $21 / 2$ & $\begin{array}{r}3 \\
\text { Loose }\end{array}$ & Tamped $21 / 2$ & $\begin{array}{r}3 \\
\text { Loose }\end{array}$ & Tamperi \\
\hline $\begin{array}{l}\text { Rise in } 1 \text { hour: } \\
\text { Speeimen } 1 \\
\text { Speeimen } 2\end{array}$ & $\begin{array}{l}1.25 \\
1.00\end{array}$ & $\begin{array}{l}\text { 1. } 50 \\
\text { I. } 25\end{array}$ & $\begin{array}{l}0.90 \\
1.00\end{array}$ & $\begin{array}{l}1.00 \\
1.00\end{array}$ & $\begin{array}{l}1.50 \\
0.50\end{array}$ & $\begin{array}{r}0.50 \\
.75\end{array}$ \\
\hline Average & 1.1 & 1.4 & 1.0 & 1. 0 & 1.0 & 0.6 \\
\hline $\begin{array}{l}\text { Rise in } 24 \text { hours: } \\
\text { Speeimen } 1 \\
\text { Speeimen } 2\end{array}$ & $\begin{array}{l}3.00 \\
1.50\end{array}$ & $\begin{array}{l}2.00 \\
2.00\end{array}$ & $\begin{array}{l}1.75 \\
1.50\end{array}$ & $\begin{array}{l}1.75 \\
1.50\end{array}$ & $\begin{array}{l}1.75 \\
2.00\end{array}$ & $\begin{array}{l}1.50 \\
1.75\end{array}$ \\
\hline A verage. & 2.2 & 2.0 & 1.6 & 1.6 & 1.9 & 1.6 \\
\hline $\begin{array}{l}\text { Kise in } 7 \text { days: } \\
\text { Speeimen } 1 \\
\text { Speeimen } 2\end{array}$ & $\begin{array}{l}6.75 \\
6.25\end{array}$ & $\begin{array}{l}5.00 \\
4.50 \\
\end{array}$ & $\begin{array}{l}3.25 \\
2.50 \\
\end{array}$ & $\begin{array}{l}3.25 \\
2.50\end{array}$ & $\begin{array}{l}3.50 \\
4.00\end{array}$ & $\begin{array}{l}3.25 \\
3.50\end{array}$ \\
\hline Average .. & 6.5 & 4.7 & 2.9 & 2.9 & 3.8 & 3.4 \\
\hline
\end{tabular}

see table 2 for aetual eement eontent.

\section{Water Penetration Due to Capillarity}

From the broken halves of the transverse-test walls, specimens $6 \mathrm{in}$. thick, 10 in. wide, and $15 \mathrm{in}$. high were stood vertically in pans containing $\frac{1}{8} \mathrm{in}$. of water. This was done in a room where the relative humidity was 80 to 85 percent and the temperature $72^{\circ}$ to $75^{\circ} \mathrm{F}$.

The maximum rise of water in the specimens was observed at $1 \mathrm{hr}, 24 \mathrm{hr}$, and at 7 days, and these values are given in table 8 . Two specimens of each set were used, one from a monolithic wall, and the second from a transverse-joint wall.

\section{Resistance to Rain Penetration}

\section{(a) Specimens}

The six specinens used for the water-perreability tests were about $51 \mathrm{in}$. high, 41 in. wirle, and 6 in. thick, with each of the three aggregates represented with the concrete tamped or placed loose. They were built on supporting channels with a 2 -in. mortar base containing a copper flashing projecting at the back, which collected any water penetrating the face during test. Similar to the heat-transfer walls, the front face, edges, and top were finished witl $1 / 8$ in. of stuceo. These walls were aged at least 1 month indoors before being tested. The walls made of grits are shown in figure 8 . On the left is the face of the tamped wall to which the stucco was later applied, and on the right may be seen the back of the wall with the concrete placed loose and the flashing embedded in the 2-in. mortar base.

\section{(b) Test Equipment and Procedure}

The water-permeability test is described in BMS82, Water Permeability of Walls Built of Masonry Units. The walls were given a preliminary test of 2 days, and then put in a drying room until they had reached constant weight before the final test. The specimens were supported on metal skids, and when clamped in position, the exposed face formed one side of a pressure chamber. An air pressure of 10 $\mathrm{lb} / \mathrm{ft}^{2}$ above atmospheric was maintained in the chamber, and water from a perforated tube was sprayed near the top edge of the exposed face at the rate of $40 \mathrm{gal} / \mathrm{hr}$.

The following observations were made durimg the test: Time required for the appearance of moisture (dampness) and of visible water on the backs of the walls; time for leakage of water from the flashing, and the maximum rate of leakage; extent of damp area on the back, inchuding that produced by the capillary rise of moisture from water on the flashings.

\section{(c) Test Results}

The arbitrary method of rating the performance, as given in BMSS2, was employed. All the walls were judged to be excellent, since they had no visible water above the flashings in 1 day, no leakage, and less than 25 percent of the wall area was damp in 5 days.

\section{Bond Strength}

Bond pull-out specimens were made to determine the value of the bond of porous con- 


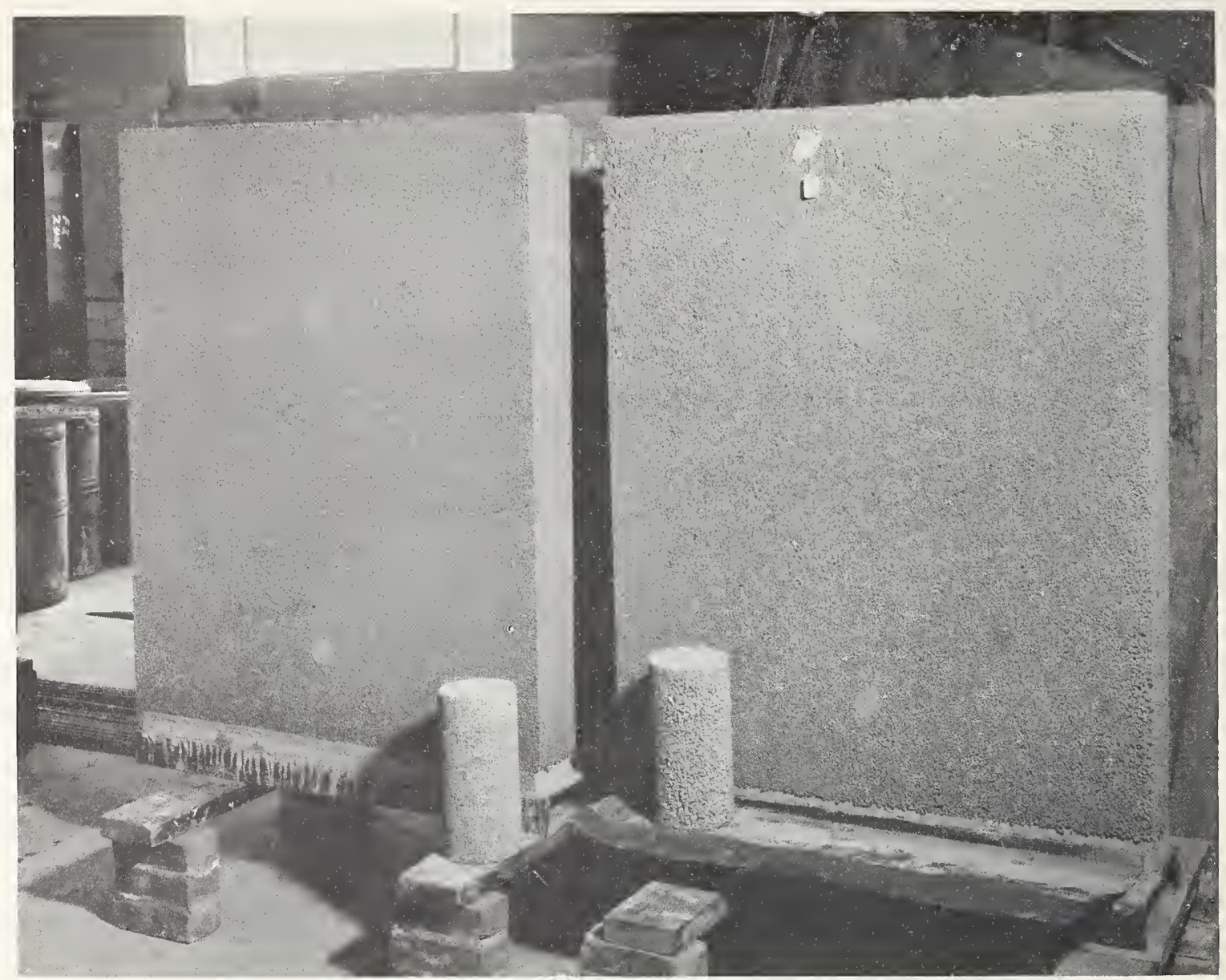

Figure 8.- Water permeabiluty specimers of porous concrete containing grits and before stuccoing.

On the left is face of wall of tamped concrete; on the right is back of wall of loose concrete.

crete as compared with that of the usual structural concrete. Porous concrete tamped in place, and made with pea gravel, using $2 \frac{1}{2}$ bags of cement per eu yd, was compared with an ordinary concrete with a compressive strength of $2,500 \mathrm{lb} / \mathrm{in}^{2}$ in the proportions of $1: 2.8: 3.2$, by volume of cement, sand, and 3/4-in. gravel. The steel used in both sets of specimens was the 3/4-in. sound deformed bar made by the Atlantic Steel Co.

Three specinrens of each type of concrete were made, 6 by 6 by 12 in. long, the bar being centered in the molds as shown in figure 9 . The specimens were made with the bar in the horizontal position; the porous concrete was tamped in place, and the regular concrete compacted with an electric vibrator. Three compressive-test cylinders of each type of concrete were made. All the specimens were stored in air in the laboratory and tested at the age of 28 days.

For testing, the bond specimens were set up as shown in figure 10. The plaster-capped base was in contact with a spherical bearing block having a 1 -ju. hole in the center, and a 0.0001 in. micrometer dial was used to measure the amount of slip of the bar at the free end.

Loads were applied to the bar, and the anount of slip as shown by the micrometer dial was reeorded for various loads. The average bond stresses for each bar were computed for a first slip of $0.0001 \mathrm{in}$. and for the maximum load and are given in table 9 .

For the porous concrete, the yield point of the steel had not been reached at bond failure, whereas in the ordinary concrete the yield point of the steel was exceeded. All specimens failed by splitting longitudinally through the center 


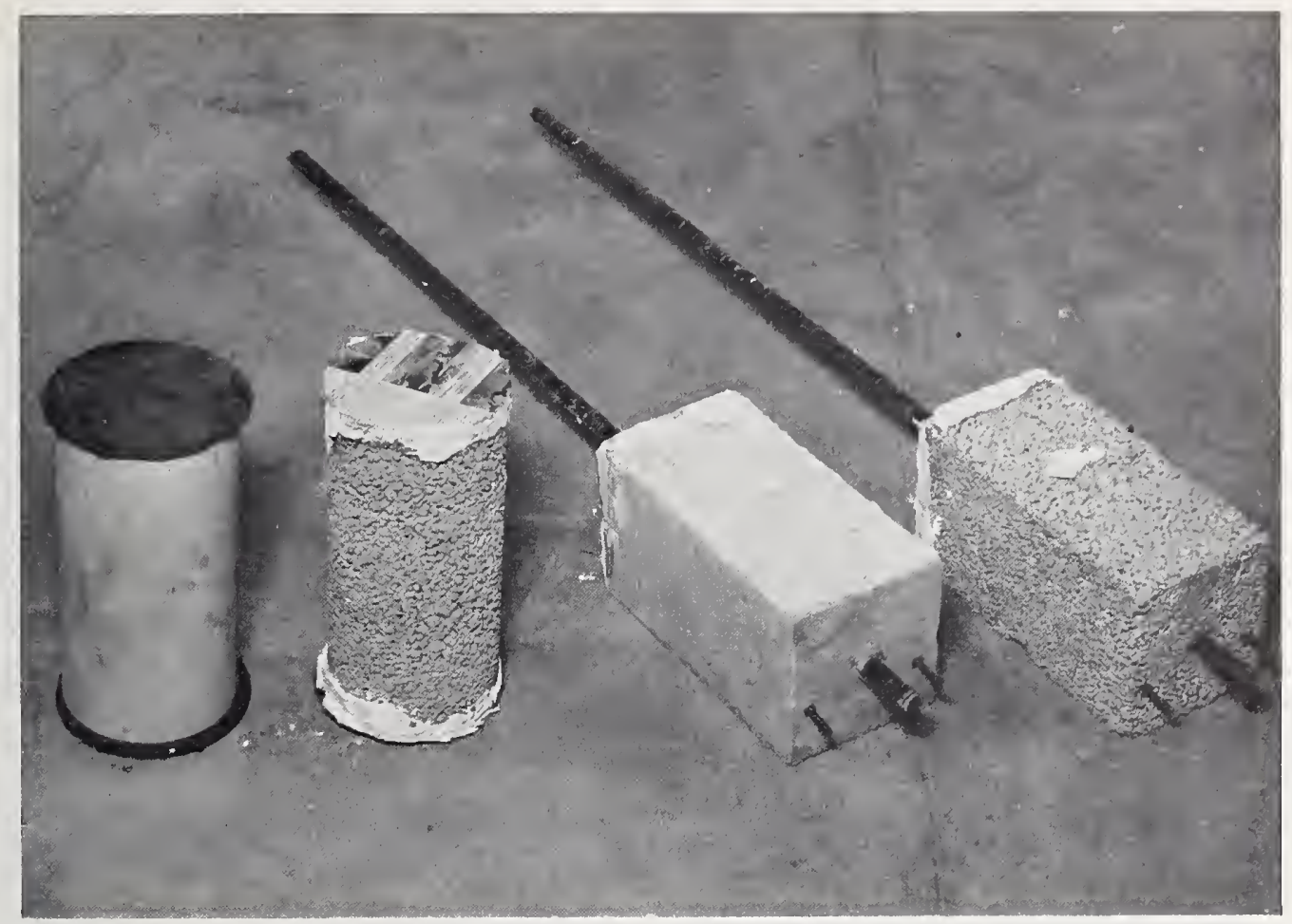

FIGURE 9.-Bond pull-oul test specimens.

in the plane paratlel to the finished surface in the position they were molded.

\section{Resistance to Failure by Diagonal Tension}

To determine resistance to diagonal tension, six beams were made of pea gravel, using $2 \frac{1}{2}$ bags of cement per eu yd, the conerete being tamped in place. The beams were $4 \mathrm{ft} 10 \mathrm{in}$. long, 6 in. wide, $13 \frac{1}{2}$ in. deep, with reinforcing steel at a depth of $12 \mathrm{in}$. Two $3 / 8$-in. round deformed bars, hooked at each end, were used as reinforcement, the bars in three of the beans being given a coating of eement grout immediately before plaeing them; in the other three beams the reinforcing was placed as delivered.

In the tests a 4 -ft span was used with the beam loaded at midspan. The maximum load was recorded, as was the load for the appearance of the first erack. The observed data are given in table 10 , and it is to be noted that specimen 3 , using the uncoated steel, failed by yielding of the tensile reinforcement, whereas the other five failed principally by diagonal tension.

TABLE 9.-Bond strenglhs as determined by pull-out specimens

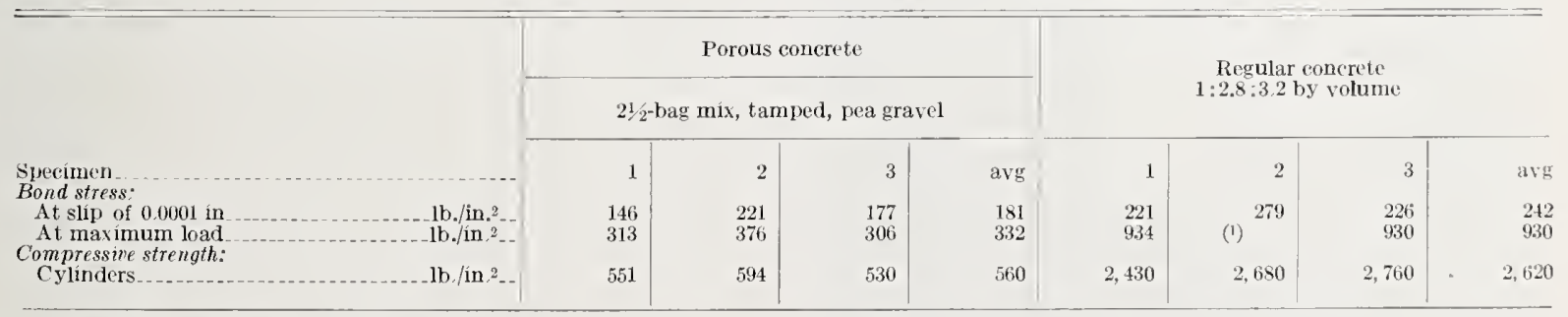

1 Loading discontinued at yield point of steel. 


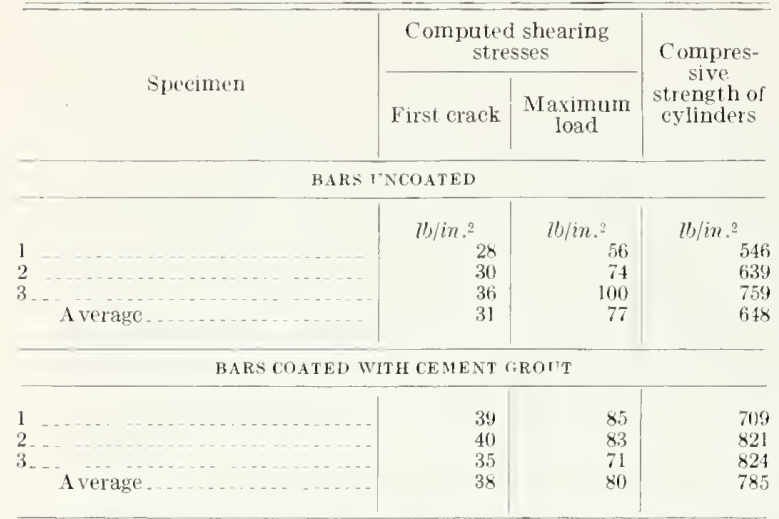

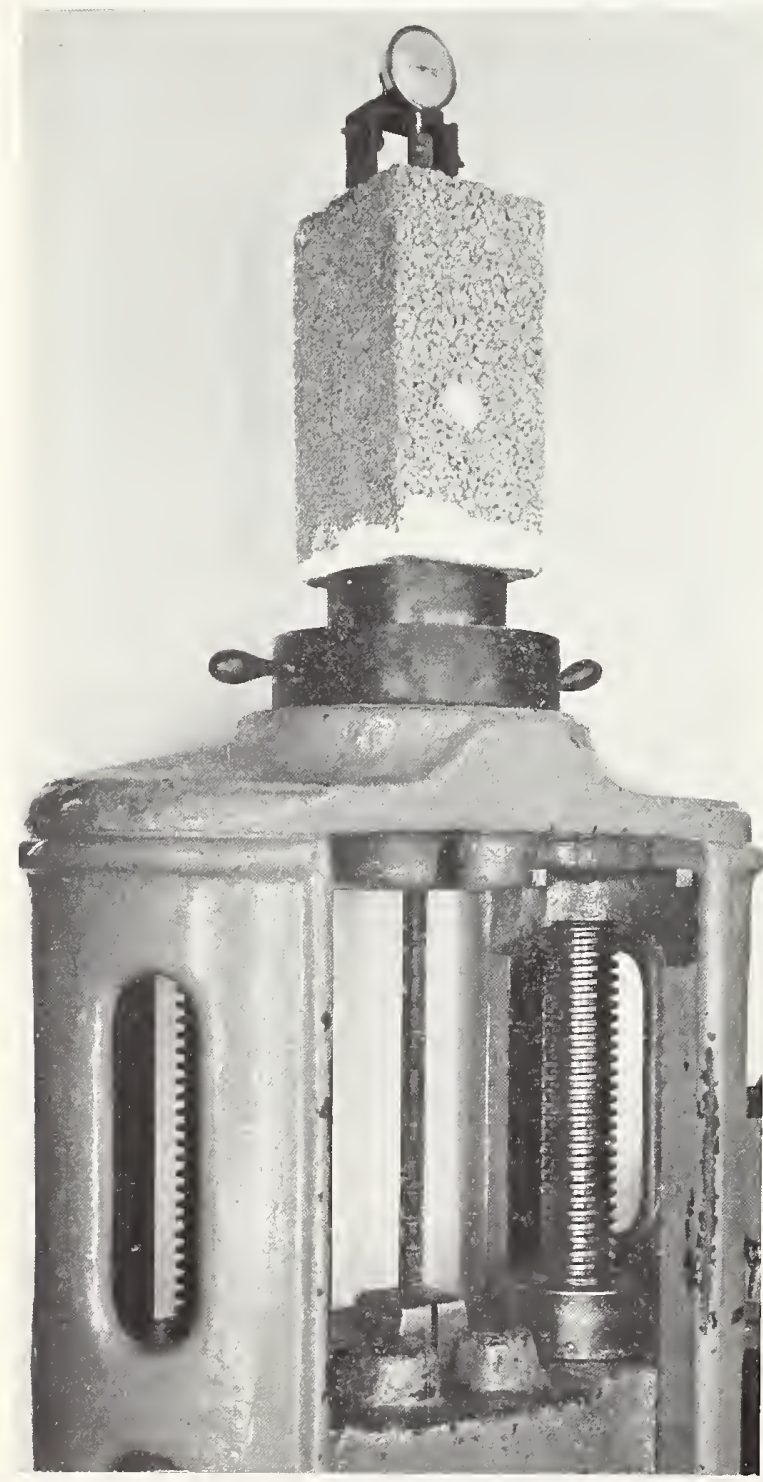

FIGURE 10.-Porous-conerete specimen in bond pull-out lest.

\section{SUMMARY}

Specimens of porous concrete consisting of cement and each of three uniform-sized gravels as aggregates (grits, pea gravel, 3/4-in. gravel) were made and tested after preliminary studies into the techniques of mixing and placing had been completed. The strengths obtamed in these preliminary studies led to the use of two mixtures for the tests, namely: 3 bags of cement per cu yd in concrete placed loose and $2 \frac{1}{2}$ bags of cement in concrete tamped in place. A summary of the results of the various tests performed, follows: ${ }^{1}$

The weight per cubic foot tended to increase with increase in size of aggregate, with a range of 97 to $105 \mathrm{lb} / \mathrm{ft}^{3}$ for that placed loose and 110 to $115 \mathrm{lb} / \mathrm{ft}^{3}$ for that tamped in place. The water-cement ratio, by weight, however, decreased with increase in size of aggregate, ranging from 0.50 to 0.40 for the loose and 0.50 to 0.44 for the tamped concrete.

The modulus of rupture for the monolithic walls was about $100 \mathrm{lb} / \mathrm{in} .^{2}$, tending to be slightly less than this value for the concrete placed loose and more for concrete placed by tamping. This value is about one-fourth of that expected for a dense concrete with a compressive strength of $2,500 \mathrm{lb} / \mathrm{in}^{2}$. The transverse strengths of walls containing a horizontal construction joint were considerably less than for walls with no joints; with the tamped porous concrete, the strength of the joint a veraged less than 25 percent of that of the monolithic wall.

The compressive strength of the tamped cylinders ranged from 600 to $900 \mathrm{lb} / \mathrm{in}^{2}$, and was a fair indication of the strength in walls

\footnotetext{
1 'The indications of this data on strength, slirinkage, resistance to rain penetration, and heat transfer are similar to those reported by the Building Rescarch Board of Great Britain, namely:

"The optimum proportion of cement to aggregate was found to he surprisingly low, a ratio of 1 part of cement to 18 parts of aggregate graded from $3 / 8$ in. to $3 / 4$ in. being found sufficicnt to cover the stones and develop a compressive strength at three months of over $400 \mathrm{lb} / \mathrm{in} .{ }^{2}$ with either gravel or dolerite.

"In respect of drying, shrinkage, and expansion on wetting, the opentextured concrete does not differ significantly from typical dense 1:2:4 concrete.

"Rendered panels of open-textured concrete 9 in. thick proved quite resistant to rain penetration. The thermal conductivity was closely similar to that of solid brickwork and dense concrete, a result which was not anticipated, the high proportion of pore space being expected to improve the thermal insulation."

Froin report of the Director of Building Research for the year 1939 . page 45 (His Majesty's Stationery Office, London).
} 
$8 \mathrm{ft}$ high and of the same mixtme. When the concrete was placed loose, the walls yielded strengths of 500 to $650 \mathrm{lb} / \mathrm{in}^{2}$, these values being 50 to $150 \mathrm{lb} / \mathrm{in} .^{2}$ higher than the strengths of their respective cylinders. The values for' secant modulus of elasticity at a stress of 200 $\mathrm{lb} /$ in. $^{2}$ ranged between one and two million $\mathrm{lb} / \mathrm{in} .^{2}$, tending to increase with increased size of aggregate.

Resistance to heat transmission decreased as the size of aggregate increased, the values of thermal transmittance, $U$, varying from 0.64 to $0.87 \mathrm{Btu} / \mathrm{hr} \mathrm{ft}^{2}{ }^{\circ} \mathrm{F}$ for 6 -in. walls, these being the corrected values for a $15-m p h$ wind outside and zero wind inside, the standard test condition recommended by the ASHVE "Guide." The "Guide" lists $U$ values of 0.77 to $0.88 \mathrm{for}$ dense concretes of various ages and mixtures.

Resistance to rain penetration of walls to which $1 / 8$-in. stucco was applied was excellent.

The coefficient of thermal expansion averaged $0.000006 /{ }^{\circ} \mathrm{F}$, approximating that of the gravel used as aggregate.

The amount of shrinkage ranged from 0.009 to 0.052 percent for the dry walls and seemed to decrease with increase in size of gravel and with the amount of compacting.

The rise of water by capillarity in walls of porous concrete ranged from 3 to $6 \frac{1}{2}$ in. at 7 days, the greater value occurring in the concrete with grits placed loose.

The bond stress at first slip between reinforc- ing steel and tamped porous concrete made of pea gravel and $2 \frac{1}{2}$ bags of cement per cu yd was abont three-fourths of that obtained for a regular concrete with a compressive strength of 2,500 lb/in." However, the maximum bond strength developed by the pull-out specimens of porous concrete was only about one-third that. of the ordinary concerete.

The computed shearing stress in the beams at laihure was about $80 \mathrm{lb} / \mathrm{in}^{2}{ }^{2}$, this vahue being about onc-half of that expected for a regular concrete with a compressive strength of 2,500 lb/in. ${ }^{2}$ The resistance to failure by diagonal tension did not change appreciably when the reinforcing bars were coated with a cementwater grout immediately before placing.

The assistance of the Federal Public Housing Authority, represented by A. M. Korsmo and B. M. Thorud, in planning the investigation, supplying information on methods of mixing and placing concrete, and in analyzing the results of the preliminary studies is gratefully acknowledged. Mr. Korsmo also reviewed the manuscript of the report and made valuable suggestions for its improvement.

The heat-transfer properties were determined by H. E. Robinson, of the Bureau's Heat Transfer Section; the water-permeability properties by C. C. Fishburn, of the Masoniy Construction Section.

Washington, December 19, 1942. 




\section{BUILDING MATERIALS AND STRUCTURES REPORTS}

\section{[Continued from cover page II]}

BMS32 Structural Properties of Two Bric-Concrete-Block Wall Constructions and a ConcreteBlock Wall Construction Sponsored by the National Concrete Masonry Association_ 10\&

BMS33

BMS34

BMS35

BMS36

BMS37

BMS38

BMS39

BMS40

BMS41

BMS42

BMS43

BMS44

BMS45

BMS46

BMS47

BMS48

BMS49

BMS50

BMS51

BMS52

BMS53

BMS54

BMS55

BMS56

BMS57

BMS58

BMS59

BMS60

BMS61

BMS62

BMS63

BMS64

BMS65

BMS66

BMS67

BMS68

BMS69

BMS70

BMS71

BMS72

BMS73

BMS74

BMS75

BMS76

BMS77

BMS78

BMS79

BMS80

BMS81 Block Wall Construct
Plastic Calking Materials

Performance Test of Floor Coverings for Use in Low-Cost Housing: Part 1 Stability of Sheathing Papers as Determined by Accelerated Aging Structural Properties of Wood-Frame Wall, Partition, Floor, and Roof Constructions with "Red Stripe" Lath Sponsored by The Weston Paper and Manufacturing Co_. $10 \notin$ Structural Properties of "Palisade Homes" Constructions for Walls, Partitions, and Floors, Sponsored by Palisade Homes _. Structural Properties of Two "Dunstone" Wall Constructions Sponsored by the W. E. Dunn Manufacturing Co Structural Properties of a Wall Construction of "Pfeifer Units" Sponsored by the Wisconsin Units Co by Knap America. Inc...... Effect of Heating and Cooling on the Permeability of Masonry Walls Structural Properties of Wood-Frame Wall and Partition Constructions with "Celotex" Insulating Boards Sponsored by The Celotex Corporation Performance Test of Floor Coverings for Use in Low-Cost Housing: Part 2. Surface Treatment of Steel Prior to Painting . Air Infiltration Through Windows Structural Properties of "Scot-Bilt" Prefabricated Sheet-Steel Constructions for Walls, Floors, and Roofs Sponsored by The Globe-Wernicke Co Structural Properties of Prefabricated Wood-Frame Constructions for Walls, Partitions, and Floors Sponsored by American Houses, Inc Sponsored by the Homasote Co.

Metallic Roofing for Low-Cost House Construction Stability of Fiber Building Boards as Determined by Accelerated Aging Structural Properties of "Tilecrete Type A" Floor Construction Sponsored by the Tilecrete Co...

Effect of Ceiling Insulation Ūpon Sumaner Conafort.

Celing Insulation Upon Sumamer Comafort Sponsol Properties of a Masonry Wall Construction of "Munlock Dry Wall Brick"
Sponsored by the Munlock Engineering Co Effect of Soot on the Rating of an Oil-Fired Heating Boiler Effects of Wetting and Drying on the Permeability of Masonry Walls... A Survey of Humidities in Residences Roofing in the United States - Results of a Questionnaire Strength of Soft-Soldered Joints in Copper Tubing Properties of Adhesives for Floor Coverings . Strength, Absorption, and Resistance to Laboratory Freezing and Thawing of Building Bricks Produced in the United States Structural Properties of Two Nonreinforced Monolithic Concrete Wall Constructions.-- $10 \%$ Structural Properties of a Precast Joist Concrete Floor Construction Sponsored by the Portland Cement Association Moisture Condensation in Building Walls Solar Heating of Various Surfaces Methods of Estimating Loads in Plumbing Systems Plumbing Manual Structural Properties of "Mu-Steel" Prefabricated Sheet-Steel Constructions for Walls, Partitions, Floor, and Roofs Sponsored by Herman A. Mugler... Performance Test for Floor Coverings for Use in Low-Cost Housing: Part $3 \ldots$ Stability of Fiber Sheathing Boards as Determined by Accelerated Aging . Asphalt-Prepared Roll Roofings and Shingles._. Fire Tests of Wood-and Metal-Framed Partitions Structural Properties of "Precision-Built, Jr." Prefabricated Wood-Frana Wall Construction Sponsored by the Homasote Co. Prefabricated Wood-Frame Wall

Indentation Characteristics of Floor Coverings Structural and Heat-Transfer Properties of "U. S. S. Panelbilt" Prefabricated SheetSteel Constructions for Walls, Partitions, and Roofs Sponsored by the Tennessee

Coal, Iron \& Railroad Co Effect of Outdoor Exposure on the Water Permeability of Masonry Walls Properties and Performance of Fiber Tile Boards Structural, Heat-Transfer, and Water-Permeability Properties of Five Earth-Wall Constructions Water-Distributing Systems for Buildings Performance Test of Floor Coverings for Use in $\mathrm{Low}-\mathrm{Cost} \mathrm{H}$ ousing: Part 4 Field Inspectors' Check List for Building Constructions (cloth cover, $5 \times 7$ i/z inches) $\ldots . . .20 \phi$ 


\section{BUILDING MATERIALS AND STRUCTURES REPORTS}

[Continued from cover page $\mathrm{nI}]$

BMS82 Water Permeability of Walls Built of Masonry Units

BMS83 Strength of Sleeve Joints in Copper Tubing Made With Various Lead-Base Solders.... 10

BMS84 Survey of Roofing Materials in the South Central States......

BMS85 Dimensional Changes of Floor Coverings with Changes in Relative Humidity and

BMS86 Structural, Heat-Transfer, and Water-Permeability Properties of "Speedbrik" Wall Construction Sponsored by the General Shale Products Corporation

BMS87 A Method for Developing Specifications for Building Construction-Report of Subcommittee on Specifications of the Central Housing Committee on Research, Design,

BMS88 Recommended Building Code Requirements for New Dwelling Construction with Special

Reference to War Housing
BMS89 Structural Properties of "Precision-Built, Jr." (Second Construction) Prefabricated Wood-Frame Wall Construction Sponsored by the Homasote Co

BMS90 Structural Properties of "PHC" Prefabricated Wood-Frame Constructions for Walls, Floors, and Roofs Sponsored by the PHC Housing Corporation.

BMS91 A Glossary of Housing Terms _

BMS92 Fire-Resistance Classifications of Building Constructions.

BMS93 Accumulation of Moisture in Walls of Frame Construction During Winter Exposure... 10 .

BMS94 Water Permeability and Weathering Resistance of Stucco-Faced, Gunite-Faced, and "Knap Concrete-Unit" Walls.

BMS95 Tests of Cement-Water Paints and Other Waterproofings for Unit-Masonry Walls

BMS96 Properties of a Porous Concrete of Cement and Uniform-Sized Gravel........... 